\title{
Die toepassing en gebruik van finansiële verhoudingsgetalle: 'n verkenningstudie
}

\author{
J.K. Bosch* \\ Departement Bedryfsekonomie, Universiteit van Port Elizabeth, Posbus 1600, Port Elizabeth 6000, Republiek van Suid-Afrika
}

A.P. du Plessis

Departement Bedryfsekonomie, Universiteit Vista: Port Elizabeth-kampus, Privaatsak X613, Port Elizabeth 6000

Republiek van Suid-Afrika

Ontvang April 1993, aanvaar November 1993

\begin{abstract}
In this article the de facto use of financial ratios is reported on. To identify meaningful financial ratios, information was obtained from 166 enterprises on the use of financial ratios. The Likert scale was used to establish the frequency of use of the following categories of financial ratios, namely return on assets, income margins, capital tumover, solvency and ratios derived from the cash flow statement. In total, 41 financial ratios were submitted to the respondents. The most important findings were: Income margins are by far the group ratios with the highest frequency of use along with the debtors collection period. Further, with the help of a multiple analysis of variance, it was established that the main activities and size of respondents had no influence on the use of specific categories of financial ratios. Finally, the findings of a factor analysis indicated noticeable similarities between theoretical groupings of financial ratios and the results of the empirical study.
\end{abstract}

\begin{abstract}
In hierdie artikel word gerapporteer oor die de facto gebruik van finansielle verhoudingsgetalle. Met die doelwit om bepaalde betekenisvolle finansiële verhoudingsgetalle te identifiseer, is inligting van 166 ondernemings met betrekking tot die gebruik van finansiële verhoudingsgetalle, verkry. Die Likertskaal is gebruik om die gebruiksfrekwensie van die volgende ses kategorieë ten opsigte van finansiële verhoudings te bepaal, naamlik rentabiliteitsverhoudings, inkomstemarges, kapitaalomset, likiditeit, solvabiliteit en verhoudings vanuit die kontantvloeistaat. In totaal is 41 finansiële verhoudingsgetalle aan die respondente voorgelê. Van die vernaamste bevindinge is die volgende: inkomstemarges is verreweg die groep verhoudingsgetalle wat die hoogste gebruiksfrekwensie vertoon saam met die debiteureinvorderingstermyn. Vervolgens is met behulp van ' $n$ meervoudige analise van variansie vasgestel dat die hoofaktiwiteite en grootte van die respondentondernemings nie ' $n$ invloed op die gebruik van bepaalde kategorieë finansiële verhoudingsgetalle het nie. Laastens het die bevindinge van 'n faktoranalise getoon dat daar merkbare ooreenkomste tussen teoretiese groeperinge van finansiële verhoudingsgetalle en die resultate van die empiriese studie bestaan.
\end{abstract}

*Aan wie korrespondensie gerig moet word.

\section{Inlelding en probleemstelling}

Daar word in die finansiële literatuur algemeen aanvaar dat die finansiěle bestuur met behoorlike inagneming van gesonde likiditeit en solvabiliteit, moet streef na die hoogs moontlike rentabiliteit en wel op 'n wyse wat die waarde van die onderneming vir die eienaars sal maksimeer (Lambrechts, 1990: 81). Gerig op die doelwit van aandeelhouerswelvaartmaksimering, moet finansiële inligting voortdurend ontleed word, want elke finansiële bestuursbesluit het op die een of ander wyse 'n invloed op die waarde van die onderneming.

Een van die mees voor-die-handliggende en geredelik beskikbare bronne van inligting is die onderneming se finansiële state, 'n belangrike inligtingsbron wat wesenlik 'n opsomming van die resultate van die kapitaalbewegings na en deur die onderneming verteenwoordig. Finansiěle analises, meer in die besonder analises deur middel van finansiële verhoudingsgetalle, is 'n nuttige hulpmiddel in die hande van die finansiële bestuur om die resultate van die kapitaalbewegings in die onderneming te ontleed.

Alhoewel finansic̈le verhoudingsgetalle normaalweg in kategoriee van rentabiliteit, likiditeit en solvabiliteit (of variasies hiervan) groepeer word, is dit moontlik om baie individuele verhoudingsgetalle te bereken. Dit is egter belangrik om daarop te wys dat die werklike nut van enige spesifieke verhoudingsgetal in 'n direkte verband met die spesifieke doelwitte van die analise verkeer. Te meer, verhoudingsgetalle is nie absolute kriteria nie en in die woorde van Helfert:
... meaningful ratios serve best to point out changes in financial conditions or operating performance and help illustrate the trends and patterns of such changes which, in turn, may indicate to the analyst the risks and opportunities for the business under review' (1991: 82).

Dit is derhalwe noodsaaklik dat die analis bepaalde betekenisvolle (of relevante) finansièle verhoudingsgetalle moet identifiseer, met die oog op die doelwit van die analise.

In die finansiěle literatuur, en in die besonder in gespesialiseerde bronne met betrekking tot finansiele verhoudingsgetalle, word indringende besprekings en illustrasies van 'n groot aantal verhoudingsgetalle gegee (Foulke, 1961; Myer, 1969; Viscione, 1977; Seitz, 1979; Foster, 1986; Lambrechts, 1990: 81-154; Maness \& Henderson, 1991; Helfert, 1991; Warren, 1991; Gibson, 1992). Aangesien dit in die praktyk nie haalbaar is om elke denkbare verhoudingsgetal te bereken nie, ontstaan derhalwe die vraag: in watter omvang en intensiteit word die finansièle verhoudingsgetalle soos voorgestel in die teorie, werklik in die sakepraktyk gebruik? Saam met hierdie probleemstelling wat op teoretiese voorskrifte en praktyktoepassings fokus, is dit nuttig om ook die siening van Paarlberg (1968) in hierdie analise te betrek. Paarlberg tref 'n insiggewende onderskeid tussen teorie en praktyk:

"There is a popular feeling that "theory" is opposed to "practice" and the merits lie with "practice". This is a 
false conclusion, based on a false supposition. If practice has long been successful and does not conform to theory, the theory is bad and in need of revision ... The distinction should not be between theory and practice; it should be between good theory and bad theory and good practice and bad practice ... Practice is brick; theory is mortar. Both are essential and both must be good if we are to erect a worthy structure' (1968: 24-25).

Hierdie mening van Paarlberg (1968: 24-25) vorm die agtergrond waarteen die totale probleem ontleed word.

\section{Finanslèle verhoudingsgetalle: 'n beknopte corsig}

Die ontleding en vertolking van finansiěle jaarstate met behulp van verhoudingsgetalle, is geen onbekende vorm van analise in die teorie en praktyk nie (Buro vir Finansięle Analise, 1989; Myer, 1969). Opsommenderwys is die volgende aspekte van finansiële verhoudingsgetalle in 'n mindere of meerdere mate bekend. As vertrekpunt dien die beskrywing van finansiële verhoudingsgetalle: 'n verhoudingsgetal is 'n eenvoudige wiskundige verwantskap tussen een relevante pos of groep relevante poste in die finansièle state en 'n ander relevante pos of groep poste. Alleenstaande is finansiële verhoudingsgetalle van min waarde: norme of finansièle standaarde word benodig om betekenis aan die vertolking te gee (Collins, 1976: 29). Verder, om insig in finansièle verhoudingsgetalle te verkry, is 'n volledige begrip van die finansiële state wat die finale produk van die rekeningkundige proses vorm, 'n noodsaaklike voorwaarde. Anders gestel, die finansiele analis moet op die hoogte met die werkswyses van die opsteller van die finansiële jaarstate wees. In hierdie opsig speel standaard rekeningkundige praktyke ook 'n rol.

Belangegroepe wat 'n belangstelling in die vertolking van finansiele jaarstate toon, sluit die volgende in: aandeelhouers (eienaars), beleggers en effekte-analiste; die bestuur van die onderneming; werknemers en vakbonde; kredietverskaffers en diverse leweransiers; klante; sommige staatsdepartemente; en die ontvanger van inkomste.

Die ontleding van finansiële state vir kredietverleningsdoeleindes in die Amerikaanse bankwêreld dateer terug tot die jaar 1895 en reeds gedurende daardie era het solvabiliteitsontledings 'n belangrike rol gespeel. In die woorde van James G. Cannon, vise-president van die Fourth National Bank of New York:

'... credit extended to the merchant must be predicated upon his solvency. This being the case, it is essential to have at hand definite knowledge as to the financial responsibility of the applicant for credit; and this information can be secured from no better source than the applicant himself' (Myer, 1969: 5).

In die beleggingsfeer, meer in die besonder by die waardering van effekte van die eerste spoorwegmaatskappye in die Verenigde State van Amerika, het begrippe soos 'the percentage of operating expenses to gross eamings' en 'the ratio of fixed charges to net income' op die voorgrond getree (Myer, 1969: 6). Ook insiggewend is die belangrike rol van die tweede likiditeitsyfer (vuurproefverhouding) by kredietverlening wat reeds in 1908 geboekstaaf is (Myer, 1969:
6). Die prominensie van die gebruik van die vlottende verhouding is ook so vroeg soos 1913 aangeteken. Teen ongeveer 1919 het insigte begin ontwikkel dat kredietverleningsbesluite nie alleen op die sterkte van die vlottende verhouding geneem kan word nie. Ander verwantskappe moet ook ontleed word.

Die ontleding van finansiele neigings met tydsverloop was teen 1925 'n gevestigde praktyk. Die identifisering van tipiese bedryfstaknorme is deur die baanbrekerswerk van James H. Bliss (1923) gedoen. Bliss (1923: viii) was van mening dat by die verskillende bedryfstakke, wat bepaal word deur die aard van die bedryfstak, daar besondere finansielle en operasionele verhoudings van toepassing is.

Finansièle verhoudingsgetalle is besonder geskik vir die daarstelling van inligting vir bestuursbesluitneming. Meer in die besonder, die uitsonderingsbeginsel kom tot sy volle reg aangesien die aandag van die bestuur op daardie aangeleenthede fokus wat werklik krities vir die onderneming is (Potgieter \& Frank, 1990: 3).

Finansiële verhoudingsgetalle speel die afgelope aantal dekades 'n belangrike rol by die evaluering van die prestasie en finansiële toestand van 'n entiteit. Deur middel van eenveranderlike en meerveranderlike diskriminantanalises is die nut van finansiěle verhoudingsgetalle telkens geillustreer deur byvoorbeeld 'n skeidslyn tussen suksesvolle en minder suksesvolle ondermemings te trek. Bekende navorsers in hierdie verband sluit in: Beaver, (1968); Altman, (1968); Deakin, (1972); Edmister, (1972); en De la Rey (1981).

\section{Doelwit en hipoteses}

Die hoofdoelwit van die studie is om meer inligting omtrent die toepassing en gebruik van relevante finansiele verhoudingsgetalle te verkry. Ter ondersteuning van die hoofdoelwit is die volgende hipoteses geformuleer:

$\mathrm{H}_{1}$ : die hoofaktiwiteite van die respondentondernemings het nie 'n invloed op die gebruik van bepaalde kategories finansiële verhoudingsgetalle nie;

$\mathrm{H}_{2}$ : die grootte van die respondentondernemings beoordeel volgens totale bates, het nie 'n invloed op die gebruik van bepaalde kategoriex finansiële verhoudingsgetalle nie;

$\mathrm{H}_{3}$ : die grootte van die respondentondememings beoordeel volgens verkoopsinkomste het nie 'n invloed op die gebruik van bepaalde kategoriex finansièle verhoudingsgetalle nie; en

$\mathrm{H}_{4}$ : die grootte van die respondentondernemings beoordeel volgens aantal werknemers het nie 'n invloed op die gebruik van bepaalde kategoriez finansiële verhoudingsgetalle nie.

\section{Omvang en metode van die navorsing}

In 'n poging om 'n objektiewe ontleding en waardebepaling met betrekking tot die toepassing en gebruik van finansiele verhoudingsgetalle te doen, asook om die navorsingshipoteses te toets, is inligting vanuit die sakepraktyk ingesamel. Nagraadse studente in Finansiěle Bestuur van die Departement Bedryfsekonomie aan die Universiteit van Port Elizabeth het senior personeel van 'n aantal geselekteerde ondernemings persoonlik besoek ten einde inligting omtrent die toepassing en gebruik van finansiěle verhoudingsgetalle te 
bekom. 'n Tweetalige vraeboog is gebruik en die inligting is deur senior personeel van die ondernemings verskaf. Die respondentondememings is almal persconlik besoek en die meerderheid ondernemings is in Streek D gevestig met die uitsondering van gevalle waar studente in ander groot stede woonagtig is, waar ondernemings vanuit daardie gebied die vraeboog voltooi het.

Die betrokkenheid van die studente by die empiriese ondersoek, is deel van 'n omvattende kurrikulum in die finansiêle bestuur. Die studente is volgens die kwaliteit van hul uitsette beoordeel en die prestasiepunt toegeken, vorm 'n deel van die finale punt. Hierdie vorm van beoordeling, gekombineer met 'n werklike belangstelling in die projek, het gelei tot entoesiastiese en konstruktiewe insette aan die kant van die studente. Altesaam 166 vraeboð was geskik vir ontleding. Die keuse van die respondentondememings is op praktiese oorwegings gegrond: die gewilligheid om studente te ontvang; die totale bates moes minstens R500 000 beloop (vervangingswaarde) en die ondernemingsvorm moet 'n maatskappy of ' $n$ beslote korporasie wees. Die opname is in 1992 gedoen.

Hierdie responsie vergelyk besonder gunstig met dié van 'n studie deur Boy (1979: 29-39) waar slegs 62 respondente van die Johannesburgse Effektebeurs aan 'n vergelykbare empiriese studie deelgeneem het.

Die vraeboog bestaan uit drie afdelings. Die eerste afdeling is gerig op die verkryging van biografiese besonderhede (soos sake-ervaring, akademiese en professionele kwalifikasies) van die hoofgebruiker van finansiële verhoudingsgetalle met die doel om 'n biografiese profiel van die gebruikers saam te stel. Die tweede afdeling is direk op 41 verskillende finansiele verhoudingsgetalle gefokus, ingedeel volgens bepaalde kategorieè, met 'n moontlike responsiekontinuum gekoppel aan 'n Likert-vyfpuntskaal (gebruiksresponsies van altyd $=100 \% ;$ meestal $=75 \% ;$ gewoonlik $=50 \% ;$ somtyds $=25 \%$ en nooit $=0 \%$ ). Benewens die verhoudingsgetalle self, is respondente ondervra ten opsigte van hul blootstelling aan die Du Pont-analise, die bepaling van vergelykingsnorme en die uitstaande voor- en nadele verbonde aan die toepassing van finansiële verhoudingsgetalle. Die derde afdeling van die vraeboog het inligting van die respondentondernemings aangevra (hoofaktiwiteite, grootte in terme van totale bates, verkoopsinkomste en totale aantal werknemers). Hierdie inligting maak kruistabulasies en die toetsing van die hipoteses moontlik.

Die vernaamste voordeel van die modus operandi soos beskryf, benewens die eenvoud, is dat dit direk op die gebruik van finansic̈le verhoudingsgetalle georiènteer is en derhalwe maklik verstaanbaar is. Moontlike kritiek mag wees dat die respondente met die vraelys kan saamstem en sodoende gebruiksfrekwensies van finansic̈le verhoudingsgetalle aandui wat van die werklikheid verwyder is.

Die BMDP (BMDP Statistical Software, 1990) statistiese pakket is gebruik om die volgende ontledings te doen: frekwensies, persentasies, gemiddelde waardes, standaardafwykings, meervoudige analise van variansie en faktoranalise.

\section{Omvang van dle responsle}

Alhoewel 166 vraebox geskik was vir ontleding, het die respondente weens verskeie redes nie op al die vrae gereageer nie. Hierdie nie-responsies is nie direk in die tabelle aangetoon nie.

Die verdeling van die respondente volgens die Standaard Nywerheidsklassifikasie verskyn in Tabel 1. Dit is opmerklik dat $63.1 \%(\mathrm{~N}=103)$ van die respondente in die vervaardigingsektor is, gevolg deur die tersiêre sektor (groot- en kleinhandel bedryfstakke).

Die gemiddelde batewaarde (vervangingswaarde) van die respondentondernemings is $\mathbf{R 8 4 . 6 5}$ miljoen (mediaan $=\mathbf{R} 20$ miljoen, modus = R10 miljoen); die verkoopsinkomste beloop gemiddeld R168.34 miljoen (mediaan en modus = R45 miljoen). Die aantal werknemers van die respondente varieer tussen 1 en 24000 , met 1163 werknemers as 'n gemiddelde waarde.

Tabel 1 Verdeling van respondente volgens die Standaard Nywerheidsklassifikasie

\begin{tabular}{|c|c|c|}
\hline Bedryfstak & Aantal & \% \\
\hline Landbow, Bosbou en Visserye & 11 & 6.7 \\
\hline Mynwese en Steengroewe & 1 & 0.6 \\
\hline \multicolumn{3}{|l|}{ Vervaardiging } \\
\hline Voedsel, drank en labak & 12 & 7.3 \\
\hline Tekstiele en klerasie & 8 & 4.9 \\
\hline Leerprodukte en skoeisel & 2 & 1.2 \\
\hline Hout en houtprodukte, insluitende meubels & 1 & 0.6 \\
\hline Papier en papierprodukte, insluitende verpakking & 6 & 3.7 \\
\hline Drukwerk en uitgewerye & 5 & 3.1 \\
\hline $\begin{array}{l}\text { Chemikalieë, petroleum, steenkool, rubber en plas- } \\
\text { tiekprodukte }\end{array}$ & 22 & 13.5 \\
\hline \multicolumn{3}{|l|}{ Nie-metaal mineraal produkte, insluitende poute- } \\
\hline Basiese yster en staalnywerhede & 2 & 1.2 \\
\hline \multicolumn{3}{|l|}{ Vervaardigde metaalprodukte, masjineric en toerus- } \\
\hline Elektriese masjinerie en toestelle & 3 & 1.8 \\
\hline Motorvoenuie, onderdele en toebehore & 12 & 7.4 \\
\hline Ander vervaardiging & 17 & 10.4 \\
\hline Sub-totaal: vervaardiging & $(103)$ & (63.1) \\
\hline Konstruksie & 5 & 3.1 \\
\hline \multicolumn{3}{|l|}{ Groot- en kle/nhandel, voedsel en huisvesting } \\
\hline Groothandel en verwante aktiwiteite & 5 & 3.1 \\
\hline Kleinhandel, uitgesonderd motor en hersteldienste & 8 & 4.9 \\
\hline Motorhandel en werkwinkels & 4 & 2.5 \\
\hline Gespesialiseerde hersteldienste & 4 & 2.5 \\
\hline Voedsel en huisvesting & 12 & 7.4 \\
\hline $\begin{array}{l}\text { Sub-totaal: grood-en kleinhandel, voedsel en huis- } \\
\text { vestig }\end{array}$ & (33) & (20.4) \\
\hline Vervoer, opberging en kommunikasie & 2 & 1.2 \\
\hline $\begin{array}{l}\text { Finansiering, versekering, eiendomontwikkeling } \\
\text { en sakedienste }\end{array}$ & 8 & 4.9 \\
\hline Totaal & 163 & 100.0 \\
\hline
\end{tabular}




\section{Blograflese Inligting van die respondente}

Die titels van die respondente is in Tabel 2 gelys. Volgens Tabel 2 is dit duidelik dat slegs senior personeel die vraeboog voltooi het met die mees algemene titels dié van finansięle rekenmeester, finansiěle bestuurder, bestuurder: finansiële beplanning en analise; en finansiêle direkteur/ besturende direkteur. Die gemiddele sake-ervaring van die respondente beloop bykans 17 jaar (mediaan = 15 jaar; modus 20 jaar).

Tabel 2 Titels van die respondente

\begin{tabular}{lcr}
\hline Titel & Amial & $\%$ \\
\hline Finansiële rekenmeester & 40 & 24.4 \\
Finansiële bestuurder. Bestuurder: finansiële beplan- & & \\
ning en analise & 43 & 26.2 \\
Finansiële Dirckteur/Besturende dirckteur & 39 & 23.8 \\
Algemene/Administratiewe Bestuurder & 13 & 7.9 \\
Diverse & 29 & 17.7 \\
\hline Tolaal & 164 & 100.0 \\
\hline
\end{tabular}

Tabel 3 Akademiese en/of professionele kwalifikasies

\begin{tabular}{lrr}
\hline Kwalifikasie & Aantal & \multicolumn{1}{c}{$\%$} \\
\hline Geoktrooieerde rekenmeester G.R. (SA) (Slegs) & 14 & 9.3 \\
B.Com, G.R. (SA) & 15 & 10.0 \\
Slegs B.Com. & 52 & 34.7 \\
B.Com. Hons & 14 & 9.3 \\
Ander Baccalaureus grade & 2 & 1.3 \\
Magistergrasd & 3 & 2.0 \\
Diverse diplomas & 42 & 28.0 \\
Slegs matriek & 8 & 5.4 \\
\hline Toral & 150 & 100.0 \\
\hline
\end{tabular}

Dit is insiggewend om op die akademiese en professionele kwalifikasies van die respondente te let (Tabel 3). Bykans twee-derdes van die respondente $(\mathrm{N}=100)$ is gegradueer en die corgrote meerheid beskik oor 'n B.Com.-graad of aanverwante kwalifikasie. Sestien respondente wou nie hul kwalifikasie bekend maak nie.

\section{Resultate}

Altesaam 41 finansielle verhoudingsgetalle, gegroepeer volgens ses kategorieð (rentabiliteit, inkomstemarges, omloopsnelhede of aktiwiteitsverhoudings, likiditeit, solvabiliteit en kontantvloeistaat) is aan die respondente vir oorweging voorgelê. Volgens 'n Likert-vyfpuntskaal moes hulle aandui of 'n besondere verhoudingsgetal altyd (100\%), meestal $(75 \%)$, gewoonlik (50\%), somtyds (25\%) of nooit (0\%) gebruik word.

Hierdie ses kategories verhoudingsgetalle, asook hul samestellende komponente en die berckeningswyse, verskyn in Bylaag A (41 verhoudingsgetalle in totaal).

Die volgende werkswyse is tydens die ontleding van die data gevolg. Eerstens is opsommende statistieke (soos die gemiddelde en standaardafwyking) bereken. Met behulp van hierdie maatstawwe is die rangordes vasgestel. Deur die gebruik van beskrywende statistiek is die data geïnspekteer alvorens tot die toetsing van die formele navorsingshipoteses, met behulp van meer gesofistikeerde statistiese tegnieke, oorgegaan is.

In 'n poging om bepaalde verwantskappe te ontleed (soos byvoorbeeld die moontlike invloed van die grootte van ondernemings by die gebruik van bepaalde kategories verhoudingsgetalle), is 'n meervoudige analise van variansie gedoen. Vir die doel van die meervoudige analise van variansie is die 41 verhoudingsgetalle in ses kategoriee ingedeel. Die indeling in kategoriez is gedoen aan die hand van die teorie (Lambrechts, 1990: 99-104).

Ten einde die teoretiese indeling van die kategoriez aan die hand van die respondente se antwoorde te toets, asook met die oog op toekomstige navorsing, is 'n faktoranalise uitgevoer. Die groepering van ses faktore ingevolge die faktoranalise is nie vir die doel van die meervoudige analise van variansie gebruik nie, aangesien die doel van die faktoranalise slegs op 'n voorlopige analise gerig is met die oog op 'n opvolgstudie.

\section{Algehele rangorde}

Vir alle respondente, sonder inagneming van die moontlike effek van hoofaktiwiteit en grootte, is 'n algehele rangorde van die finansiêle verhoudingsgetalle volgens die gemiddelde en standaardafwyking bereken. Hierdie inligting verskyn in Tabel 4A. Insiggewend is dié verhoudingsgetalle wat 'n gebruiksintensiteit van gemiddeld meer as $80 \%$ vertoon: ondernemingsinkomstemarge (85.9\%), bruto inkomstemarge (84.5\%) en debiteure invorderingstermyn (81.9\%).

Nieteenstaande die status van ondememingsrentabiliteit (nuim) as 'n primêre doelwit van die onderneming, verskyn hierdie verhouding in die agtste plek (71.5\%) en verder in respektiewelike volgordes 15 en 16, die eng berekening van ondernemingsrentabiliteit $(45.7 \%)$ en die rentabiliteit van die eie kapitaal (42.3\%). Die kontantvloei-omset-verhouding (rangorde 19) is die eerste verhouding uit die kontantvloeistaat in die algehele rangorde.

Die rangorde van Tabel $4 \mathrm{~A}$ verskil nie aansienlik van die rangorde van Boy (1979: 37) nie. In die studie van Boy is 22 verhoudingsgetalle volgens die persepsies van die bestuur in orde van belangrikheid geplaas. Slegs 50 genoteerde maatskappye het op daardie besondere deel van Boy (1979: 35-36) se studie gereageer. Ooreenstemmende verhoudingsgetalle van hierdie studie en in die van Boy (onder die eerste tien) sluit in die bruto inkomstemarge, die debiteure invorderingstermyn, die vlottende verhouding, die netto inkomstemarge, die ondernemingsrentabiliteit (ruim) en die omloopsnelheid van voorrade.

Kruistabulasies is gedoen met die gesamentlike respondente van die primêre en sekondêre sektore as onafhanklike veranderlikes (Tabel 4B) en die tersiêre sektor as onafhanklike veranderlike (Tabel 4C). Van belang is kolomme 6 en 7 van albei tabelle wat die rangordeverskille aandui. 
Volgens Tabel 4B (kolom 6) blyk dit dat die rangorde van die genoemde respondente vir die eerste 16 verhoudingsgetalle nie van die algehele rangorde (Tabel 4A) verskil nie. Rangorde 17 van Tabel 4B (vreemde kapitaalverhouding) verskyn een plek laer in Tabel $4 A$ (kyk na kolom 6). Die vertolking is soortgelyk aan kolom 7 van Tabelle $4 B$ en $4 C$.

\section{Rangorde per kategorie verhoudingsgetalle}

Soos reeds aangedui is die 41 verhoudingsgetalle (kyk ook na Bylaag A) in ses kategoriee verdeel - 'n kategorisering met onderverdelings soos dit algemeen in die finansiêle literatuur (Lambrechts, 1990: 99-104) voorgestel word.
Volgens Tabel 4D blyk dit dat inkomstemarges as 'n $\mathbf{k i}$ tegorie gemiddeld die hoogste gebruiksorde vertoc (68.9\%), gevolg deur likiditeitsverhoudinge (63.8\%), on loopsnelhede $(55.2 \%)$, rentabiliteitsberekeninge (41.5\% solvabiliteitsberekeninge $(26.8 \%)$ en verhoudinge uit di kontantvloeistaat (20.8\%).

\section{Meervoudige analise van variansle}

Dit is moontlik om deur middel van 'n meervoudige analis van variansie die verwantskappe tussen verskeie onafhanl like en afhanklike veranderlikes te ontleed. In hierdie studj is die onafhanklike veranderlikes die aard van die hoo:

Tabel 4A Algehele rangorde van finansiële verhoudingsgetalle $(N=163)$

\begin{tabular}{|c|c|c|c|c|}
\hline $\begin{array}{l}\text { Rang- } \\
\text { orde }\end{array}$ & Verhoudingsgetal & Gemiddelde & $\begin{array}{l}\text { Standasard- } \\
\text { afwyking }\end{array}$ & $\begin{array}{l}\text { Koäffisiěnt } \\
\text { van variasie }\end{array}$ \\
\hline 1 & Ondememingsinkomstemarge & 85.89 & 29.53 & 0.34 \\
\hline 2 & Bruto inkomstemarge & 84.53 & 31.21 & 0.37 \\
\hline 3 & Debiteure invorderingstermyn & 81.88 & 33.41 & 0.41 \\
\hline 4 & Bedryfsmarge & 77.19 & 37.03 & 0.48 \\
\hline 5 & Vlottende verhouding & 74.84 & 36.07 & 0.48 \\
\hline 6 & Netto inkomstemarge & 72.77 & 39.77 & 0.55 \\
\hline 7 & Debiteure omloopsnelheid & 71.88 & 40.22 & 0.56 \\
\hline 8 & Ondememingsrentabiliteit (ruim) & 71.45 & 38.09 & 0.53 \\
\hline 9 & Dae se verkope in voorrand & 71.32 & 40.08 & 0.56 \\
\hline 10 & Voorraadomloopsnelheid & 69.22 & 41.33 & 0.60 \\
\hline 11 & Vuurproefverhouding & 63.85 & 41.64 & 0.65 \\
\hline 12 & Omloopsnelheid van totale bates & 62.89 & 42.12 & 0.67 \\
\hline 13 & Betalingstermyn van handelskrediteure & 58.65 & 41.72 & 0.71 \\
\hline 14 & Omloopsnelheid van vlottende bates & 48.72 & 40.74 & 0.84 \\
\hline 15 & Ondememingsrentsbiliteit (eng) & 45.73 & 44.45 & 0.97 \\
\hline 16 & Rentabiliteit van eic kapitaal & 42.26 & 43.26 & 1.02 \\
\hline 17 & Omloopsnelheid van vaste bates & 41.23 & 39.45 & 0.96 \\
\hline 18 & Vreernde kapitaalverhouding & 39.08 & 40.84 & 1.04 \\
\hline 19 & Kontantvloei-omset-verhouding & 36.69 & 41.14 & 1.12 \\
\hline 20 & Finansiële hefboomfaktor & 36.53 & 42.70 & 1.17 \\
\hline 21 & Rentedekkingverhoudingsgetal & 35.67 & 40.45 & 1.13 \\
\hline 22 & Rentabiliteit van vreemde kapitaal & 34.78 & 38.69 & 1.11 \\
\hline 23 & Solvabiliteitsverhouding & 34.19 & 39.27 & 1.15 \\
\hline 24 & Kontantverhouding & 30.00 & 38.48 & 1.28 \\
\hline 25 & Rentabiliteit van beherende kapitaal & 29.84 & 42.08 & 1.41 \\
\hline 26 & Omloopsnelheid van kontant & 29.62 & 39.61 & 1.34 \\
\hline 27 & Rentabiliteit van beleggings & 27.35 & 38.04 & 1.39 \\
\hline 28 & Kontemyn vreemde kapitaal: eie kapitaal & 25.00 & 34.66 & 1.39 \\
\hline 29 & Verdienste en dividend per aandeel & 23.87 & 39.20 & 1.64 \\
\hline 30 & Kontermyn vreemde kapitaal: totale vreemde kapitaal & 23.85 & 35.86 & 1.50 \\
\hline 31 & Langtermyn vreemde kapitaal: totale vreemde kapitaal & 23.21 & 35.48 & 1.53 \\
\hline 32 & Netto vlottende bate tot kontant uit ondememingsaktiwiteite & 22.88 & 34.29 & 1.50 \\
\hline 33 & Vlottende bate-omsetverandering & 22.40 & 34.44 & 1.54 \\
\hline 34 & Gewone dividenddekking & 20.83 & 37.33 & 1.79 \\
\hline 35 & Kontantvloei vir finansieringskoste & 20.75 & 35.79 & 1.72 \\
\hline 36 & Kontantinvesteringsverhouding & 18.91 & 34.04 & 1.80 \\
\hline 37 & Vaste verpligtingedekking & 13.87 & 27.94 & 2.01 \\
\hline 38 & Eksploitasiekoëffisiënt & 12.67 & 29.09 & 2.30 \\
\hline 39 & Dividende uit kontantvloei & 11.51 & 28.47 & 2.47 \\
\hline 40 & Kontant vir kapitaalaflossing & 10.86 & 26.63 & 2.45 \\
\hline 41 & Voorkeurdividenddekking & 8.82 & 25.40 & 2.88 \\
\hline
\end{tabular}


Tabel 4B Rangorde van respondente vanuit die primêre en sekondêre sektore $(N=120)$

\begin{tabular}{|c|c|c|c|c|c|c|}
\hline $\begin{array}{l}\text { (1) } \\
\text { Rang- } \\
\text { onde }\end{array}$ & $\begin{array}{l}\text { (2) } \\
\text { Verhoudingsgetal }\end{array}$ & $\begin{array}{c}\text { (3) } \\
\text { Gemiddelde }\end{array}$ & $\begin{array}{l}\text { (4) } \\
\text { Standaard- } \\
\text { afwyking }\end{array}$ & $\begin{array}{c}\text { (5) } \\
\text { Koëffisiënt } \\
\text { van variasie }\end{array}$ & $\begin{array}{l}\text { (6) } \\
\text { Rangorde verskil } \\
\text { met algeheel } \\
\text { (Tabel 4A) }\end{array}$ & $\begin{array}{l}\quad(7) \\
\text { Rangorde verskil } \\
\text { met tersiêre } \\
\text { sektor } \\
\text { (Tabel } 4 C)\end{array}$ \\
\hline 1 & Ondememingsinkomstemarge & 87.19 & 28.72 & 0.33 & 0 & 0 \\
\hline 2 & Bruto inkornstemarge & 85.99 & 29.91 & 0.35 & 0 & 0 \\
\hline 3 & Debiteure invorderingstemyn & 82.69 & 33.87 & 0.41 & $\mathbf{0}$ & 0 \\
\hline 4 & Bedryfsmarge & 81.30 & 34.48 & 0.42 & $\mathbf{0}$ & 6 \\
\hline 5 & Vloutende verhouding & 77.14 & 35.59 & 0.46 & $\mathbf{0}$ & 1 \\
\hline 6 & Netuo inkornstemarge & 74.12 & 38.20 & 0.52 & $\mathbf{0}$ & -1 \\
\hline 7 & Debiteure omloopsnelheid & 72.63 & 40.24 & 0.55 & $\mathbf{0}$ & 2 \\
\hline 8 & Ondememingsrentabiliteit (ruim) & 72.46 & 37.47 & 0.52 & 0 & 0 \\
\hline 9 & Dae se verkope in voorraed & 71.64 & 40.25 & 0.56 & 0 & -2 \\
\hline 10 & Voorrasdomloopsnelheid & 68.32 & 41.88 & 0.61 & 0 & -6 \\
\hline 11 & Vuurproefverhouding & 65.13 & 41.89 & 0.64 & 0 & 1 \\
\hline 12 & Omloopsnelheid van totale bales & 63.25 & 42.87 & 0.68 & 0 & -1 \\
\hline 13 & Betalingstermyn van handelskrediteure & 58.97 & 41.71 & 0.71 & 0 & 0 \\
\hline 14 & Omloopsnelheid van vlottende bates & 48.26 & 40.79 & 0.85 & 0 & 2 \\
\hline 15 & Ondememingsrentabiliteit (eng) & 44.18 & 43.78 & 0.99 & 0 & $\mathbf{0}$ \\
\hline 16 & Rentabiliteit van eie kapitaal & 42.76 & 43.33 & 1.01 & 0 & 2 \\
\hline 17 & Vreemde kapitaalverhouding & 40.09 & 41.82 & 1.04 & 1 & 2 \\
\hline 18 & Vaste bates omloopsnelheid & 38.38 & 38.96 & 1.02 & -1 & -4 \\
\hline 19 & Rentabiliteit van vreemde kapitaal & 37.50 & 38.82 & 1.04 & 3 & 7 \\
\hline 20 & Rentedekkingsverhoudihgsgetal & 36.18 & 40.34 & 1.11 & 1 & 1 \\
\hline 21 & Finansiële hefboomfaktor & 36.16 & 43.35 & 1.20 & -1 & -1 \\
\hline 22 & Solvabiliteitsverhouding & 34.13 & 39.09 & 1.15 & 1 & 2 \\
\hline 23 & Kontantvloei-omset-verhouding & 34.07 & 40.24 & 1.18 & -4 & -6 \\
\hline 24 & Rentabiliteit van beherende kapitaal & 31.14 & 43.05 & 1.38 & 1 & 5 \\
\hline 25 & Omloopsnelheid van kontant & 28.76 & 38.85 & 1.35 & 1 & -2 \\
\hline 26 & Kontantverhouding & 28.35 & 37.74 & 1.33 & -2 & -4 \\
\hline 27 & Rentabiliteit van beleggings & 27.32 & 39.20 & 1.44 & 0 & 1 \\
\hline 28 & Kontermyn vreemde kapitaal: eie kapitaal & 26.09 & 36.03 & 1.38 & 0 & 5 \\
\hline 29 & $\begin{array}{l}\text { Kontermyn vreemde kapitaal: totale vreem- } \\
\text { de kapitaal }\end{array}$ & 24.55 & 36.46 & 1.49 & 1 & 5 \\
\hline 30 & Gewone dividenddekking & 23.06 & 39.58 & 1.72 & 4 & 8 \\
\hline 31 & Opbrengsverhoudings (VPA en DPA) & 23.03 & 39.23 & 1.70 & -2 & 0 \\
\hline \multirow[t]{2}{*}{32} & Langtemyn vreemde kapitaal: totale & & & & & \\
\hline & vreemde kapitaal & 21.68 & 34.32 & 1.58 & -1 & -7 \\
\hline 33 & $\begin{array}{l}\text { Neuo vlouende bate lot kontant uit onder- } \\
\text { nemingsaktiwiteite }\end{array}$ & 21.65 & 32.79 & 1.51 & -1 & -1 \\
\hline 34 & Vlottende bete-omsetverandering & 20.80 & 31.50 & 1.51 & -1 & -7 \\
\hline 35 & Kontantvloei vir finansiëringskoste & 20.31 & 35.60 & 1.75 & $\mathbf{0}$ & 1 \\
\hline 36 & Kontant-investeringsverthouding & 16.89 & 30.74 & 1.82 & 0 & 1 \\
\hline 37 & Dividende uit kontantvloei & 11.16 & 27.84 & 2.49 & 2 & 3 \\
\hline 38 & Vade verpligtingedekking & 10.18 & 22.82 & 2.24 & -1 & -8 \\
\hline 39 & Kontant vir kapitaalaflossing & 10.05 & 24.99 & 2.49 & 1 & 2 \\
\hline 40 & Eksploitasiekoëffisiënt & 9.40 & 24.25 & 2.58 & -2 & -5 \\
\hline 41 & Voorkeurdividenddekking & 7.14 & 23.11 & 3.24 & $\mathbf{0}$ & -2 \\
\hline
\end{tabular}

aktiwiteite van die respondente (vervaardiging en dienslewering) en grootte (beoordeel volgens batewaardes, verkoopsinkomste en aantal werknemers). Die afhanklike veranderlikes is in die reeds genoemde ses kategoriex verhoudingsgetalle saamgevat.

By die meervoudige analise van variansie word die ver- wantskappe tussen die onafhanklike (gesamentlik) en afhanklike veranderlikes met behulp van F-toetse ondersoek. Die p-waardes wat verkry is, word by die hipotesetoetsing gebruik: indien $p<0.05$, dan bestaan daar statisties beduidende verwantskappe tussen die veranderlikes.

Die berekende p-waardes verskyn in Tabel 5 , bereken vir 
Tabel 4C Rangorde van respondente vanuit die tersiêre sektor $(N=43)$

\begin{tabular}{|c|c|c|c|c|c|c|}
\hline $\begin{array}{l}\text { (1) } \\
\text { Rang- } \\
\text { orde }\end{array}$ & Verhoudingsgetal & $\begin{array}{c}\text { (3) } \\
\text { Gemiddelde }\end{array}$ & $\begin{array}{c}\text { (4) } \\
\text { Standand- } \\
\text { f wyking }\end{array}$ & $\begin{array}{c}\text { (5) } \\
\text { Koeffisiěnt } \\
\text { van variasie }\end{array}$ & $\begin{array}{c}\text { (6) } \\
\text { Rangorde verskil } \\
\text { ma algeheel } \\
\text { (Tabel 4A) }\end{array}$ & $\begin{array}{c}\text { (7) } \\
\text { Rangorde verakil } \\
\text { met primêre an } \\
\text { sekondére sektore } \\
\text { (Trabel 4B) }\end{array}$ \\
\hline 1 & Ondernemingsinkomstemarge & 83.54 & 29.90 & 0.36 & $\mathbf{0}$ & $\mathbf{0}$ \\
\hline 2 & Bruto inkornstemarge & 82.14 & 32.80 & 0.40 & 0 & $\mathbf{0}$ \\
\hline 3 & Debiteure invorderingstermyn & 78.66 & 32.86 & 0.42 & $\mathbf{0}$ & $\mathbf{0}$ \\
\hline 4 & Voorraadomloopsnelheid & 70.24 & 40.66 & 0.58 & 6 & 6 \\
\hline 5 & Netto inkomstemarge & 70.12 & 43.38 & 0.62 & 1 & 1 \\
\hline 6 & Vlottende verhouding & 69.51 & 36.02 & 0.52 & -1 & -1 \\
\hline 7 & Dae se verkope in voorraad & 69.05 & 40.50 & 0.59 & 2 & 2 \\
\hline 8 & Ondememingsrentabiliteit (ruim) & 68.90 & 39.44 & 0.57 & $\mathbf{0}$ & 0 \\
\hline 9 & Debiteure omloopsnelheid & 68.45 & 40.97 & 0.60 & -2 & -2 \\
\hline 10 & Bedryfsmarge & 66.03 & 41.15 & 0.62 & -6 & -6 \\
\hline 11 & Omloopsnelheid van totale bates & 63.42 & 39.96 & 0.63 & 1 & 1 \\
\hline 12 & Vuurproefverhouding & 60.98 & 41.85 & 0.69 & -1 & -1 \\
\hline 13 & Betalingstermyn van handelskrediteure & 55.63 & 42.17 & 0.76 & 0 & $\mathbf{0}$ \\
\hline 14 & Omloopsnelheid van vaste bates & 51.32 & 40.25 & 0.78 & 3 & 4 \\
\hline 15 & Ondememingsrentabiliteit (eng) & 50.00 & 46.34 & 0.93 & 0 & $\mathbf{0}$ \\
\hline 16 & Omloopsnelheid van vlottende bates & 48.75 & 40.81 & 0.84 & -2 & -2 \\
\hline 17 & Kontantvloei-omset-verhouding & 44.87 & 43.75 & 0.97 & 2 & 6 \\
\hline 18 & Rentabiliteit van eie kapitaal & 37.82 & 42.49 & 1.12 & -2 & -2 \\
\hline 19 & Vreemde kapitaalverhouding & 36.88 & 39.22 & 1.06 & -1 & -2 \\
\hline 20 & Finansiële hefboomfaktor & 36.88 & 40.82 & 1.11 & $\mathbf{0}$ & 1 \\
\hline 21 & Rentedekkingsverhoudingsgetal & 35.98 & 41.48 & 1.15 & $\mathbf{0}$ & -1 \\
\hline 22 & Kontant verhouding & 35.37 & 41.07 & 1.16 & 2 & 4 \\
\hline 23 & Omloopsnelheid van kontant & 33.33 & 42.29 & 1.27 & 3 & 2 \\
\hline 24 & Solvabiliteitsverhouding & 32.90 & 39.89 & 1.21 & -1 & -2 \\
\hline 25 & Langtermyn VK: Totale VK & 28.85 & 39.13 & 1.36 & 6 & 7 \\
\hline 26 & Rentabiliteit van vreemde kapitaal & 28.75 & 38.21 & 1.33 & -4 & -7 \\
\hline 27 & Vlottende bate-ornsetverandering & 28.21 & 42.22 & 1.50 & 6 & 7 \\
\hline 28 & Rentabiliteit van beleggings & 27.56 & 35.72 & 1.30 & -1 & -1 \\
\hline 29 & Rentabiliteit van beherende kapitaal & 27.56 & 40.06 & 1.45 & -4 & -5 \\
\hline 30 & Vaste verpligtinge dekking & 25.00 & 37.55 & 1.50 & 7 & 8 \\
\hline 31 & Opbrengsverhoudings (VPA en DPA) & 25.00 & 38.47 & 1.54 & -2 & $\mathbf{0}$ \\
\hline 32 & $\begin{array}{l}\text { Netto vlottende bate to kontant uit onder- } \\
\text { nemingsaktiwiteite }\end{array}$ & 23.72 & 37.15 & 1.57 & 0 & 1 \\
\hline 33 & Kontermyn VK: Eie kapitaal & 23.08 & 31.09 & 1.35 & -5 & -5 \\
\hline 34 & Kontermyn VK: Totale VK & 23.08 & 35.07 & 1.52 & -4 & -5 \\
\hline 35 & Eksploitasiekoëffisiënt & 22.97 & 39.26 & 1.71 & 3 & 5 \\
\hline 36 & Kontantvloei vir finansieringskoste & 22.44 & 37.52 & 1.67 & -1 & -1 \\
\hline 37 & Kontant-investeringsverhouding & 20.51 & 38.85 & 1.89 & -1 & -1 \\
\hline 38 & Gewone dividenddekking & 15.13 & 29.94 & 1.98 & -4 & -8 \\
\hline 39 & Vorkeurdividenddekking & 14.10 & 31.31 & 2.22 & 2 & 2 \\
\hline 40 & Dividende uit kontantvloei & 13.16 & 31.16 & 2.37 & -1 & -3 \\
\hline 41 & Kontant vir kapitaalaflossing & 13.16 & 31.70 & 2.41 & -1 & -2 \\
\hline
\end{tabular}

'n verdeling in kategorier volgens beide kwartiel- en mediaanwaardes ten opsigte van die onafhanklike veranderlikes met betrekking tot die grootte van die respondente.

Die navorsingshipoteses poneer dat onafhanklike veranderlikes soos hoofaktiwiteite en grootte van respondentondernemings nie ' $n$ invloed op die gebruik van bepaalde kategorieè finansiële verhoudingsgetalle het nie. Volgens die resultaat van die meervoudige analise van variansie (Tabel
5) blyk dit asof hipoteses $H_{1}, H_{2}, H_{3}$ en $H_{4}$ nie verwerp kan word nie aangesien die $\mathrm{p}$-waardes met die uitsondering van een, almal groter as 0.05 is. Die uitsondering is by die mediaanverdeling van verkoopsinkomste (as onafhanklike veranderlike) en die solvabiliteitsverhoudings waar daar wel 'n statistiese beduidende verwantskap bestaan. Geen verdere ontleding is uitgevoer om hierdie verwantskap te verklaar nie. 
Tabel 4D Rangorde van kategorieě verhoudingsgetalle $(N=163)$

\begin{tabular}{|c|c|c|c|c|}
\hline $\begin{array}{l}\text { Kategoric } \\
\text { rangorde }\end{array}$ & $\begin{array}{l}\text { Kategorie } \\
\text { Verhoudingsgetal }\end{array}$ & Gemiddelde & $\begin{array}{l}\text { Standaard- } \\
\text { afwyking }\end{array}$ & $\begin{array}{l}\text { Koefffisiënt } \\
\text { van variasie }\end{array}$ \\
\hline \multirow[t]{6}{*}{1} & Inkomstemarges & 68.86 & 23.77 & 0.35 \\
\hline & Ondememingsinkomstemarge & 85.89 & 29.53 & 0.34 \\
\hline & Bruto inkomstemarge & 84.53 & 31.21 & 0.37 \\
\hline & Bedryfsmarge & 77.19 & 37.03 & 0.48 \\
\hline & Netto inkomstemarge & 72.77 & 39.77 & 0.55 \\
\hline & Eksploitasiek@ëffisiënt & 12.67 & 29.09 & 2.30 \\
\hline \multirow[t]{7}{*}{2} & Llkiditeitsverhoudinge & 63.82 & 25.22 & 0.40 \\
\hline & Debiteure invorderingstermyn & 81.88 & 33.41 & 0.41 \\
\hline & Vlouende verhouding & 74.84 & 36.07 & 0.48 \\
\hline & Dae se verkope in voorrand & 71.32 & 40.08 & 0.56 \\
\hline & Vuurproefverhouding & 63.85 & 41.64 & 0.65 \\
\hline & Betalingstermyn van handelskrediteure & 58.65 & 41.72 & 0.71 \\
\hline & Kontantverhouding & 30.00 & 38.48 & 1.28 \\
\hline \multirow[t]{7}{*}{3} & Omloopsnelhede & 55.18 & 27.68 & 0.50 \\
\hline & Debiteure & 71.88 & 40.22 & 0.56 \\
\hline & Voorrand & 69.22 & 41.33 & 0.60 \\
\hline & Totale bates & 62.89 & 42.12 & 0.67 \\
\hline & Vlotiende bates & 48.72 & 40.74 & 0.84 \\
\hline & Vaste bates & 41.23 & 39.45 & 0.96 \\
\hline & Kontant & 29.62 & 39.61 & 1.34 \\
\hline \multirow[t]{9}{*}{4} & Rentablitielt & 41.48 & 30.47 & 0.73 \\
\hline & Ondememingsrentabiliteit (nuim) & 71.45 & 38.09 & 0.53 \\
\hline & Ondememingsrentabiliteit (eng) & 45.73 & 44.45 & 0.97 \\
\hline & Rentabiliteit van eie kapitaal & 42.26 & 43.26 & 1.02 \\
\hline & Finansiële hefboomfaktor & 36.53 & 42.70 & 1.17 \\
\hline & Rentabiliteit van vreemde kapitaal & 34.78 & 38.69 & 1.11 \\
\hline & Rentabiliteit van beherende kapitaal & 29.84 & 42.08 & 1.41 \\
\hline & Rentabiliteit van beleggings & 27.35 & 38.04 & 1.39 \\
\hline & Verdienste en dividend per aandeel & 23.87 & 39.20 & 1.64 \\
\hline \multirow[t]{10}{*}{5} & Solvabiliteit & 26.81 & 27.28 & 1.02 \\
\hline & Vreemde kapitaalverhouding & 39.08 & 40.84 & 1.04 \\
\hline & Rentedekkingsverhoudingsgetal & 35.67 & 40.45 & 1.13 \\
\hline & Solvabiliteitsverhouding & 34.19 & 39.27 & 1.15 \\
\hline & Kontermyn vreemde kapitaal: eie kapitalal & 25.00 & 34.66 & 1.39 \\
\hline & Kontermyn vreemde kapitaal: totale vreemde kapitaal & 23.85 & 35.86 & 1.50 \\
\hline & Langtermyn vreemde kapitaal: totale vreende kapitaal & 23.21 & 35.48 & 1.53 \\
\hline & Gewone dividenddekking & 20.83 & 37.33 & 1.79 \\
\hline & Vaste verpligtinge dekking & 13.87 & 27.94 & 2.01 \\
\hline & Voorkeurdividenddekking & 8.82 & 25.40 & 2.88 \\
\hline \multirow[t]{9}{*}{6} & Kontantvloeistaat & 20.77 & 25.07 & 1.21 \\
\hline & Kontantvløei-omset-verhouding & 36.69 & 41.14 & 1.12 \\
\hline & Neuo vloutende bate tor kontant uit ondememings- & & & \\
\hline & aktiwiteite & 22.88 & 34.29 & 1.50 \\
\hline & Vloutende bate omsetverandering & 22.40 & 34.44 & 1.54 \\
\hline & Kontantvloei vir finansieringskoste & 20.75 & 35.79 & 1.72 \\
\hline & Kontant-investeringsverhouding & 18.91 & 34.04 & 1.80 \\
\hline & Dividende uit kontantvloei & 11.51 & 28.47 & 2.47 \\
\hline & Kontant vir kapitaalaflossing & 10.86 & 26.63 & 2.45 \\
\hline
\end{tabular}

\section{Faktoranalise}

Faktoranalise is 'n tegniek wat data van 'n relatiewe groot aantal veranderlikes analiseer en dan 'n kleiner groep van faktore genereer op grond van liniêre kombinasies van die corspronklike data (Parasuraman, 1991: 757; Lee, 1985:
79-80). Deur middel van faktoranalise word die veranderlikes wat bymekaar behoort, bepaal (verhoudingsgetalle by hierdie studie), dit wil sê die byeenbring van daardie veranderlikes wat dieselfde aspek meet of beoordeel. So ' $n$ groep veranderlikes wat dieselfde aspek meet of beoordeel, 
Tabel 5 Analise van kategorieè verhoudingsgetalle volgens hoofaktiwiteit en grootte (batewaarde, verkoopsinkomste en werknemers)

\begin{tabular}{|c|c|c|c|c|c|c|c|c|}
\hline \multirow{2}{*}{$\begin{array}{l}\text { Kategorie } \\
\text { verhoudingsgetalle }\end{array}$} & \multicolumn{2}{|c|}{$\begin{array}{c}\text { Sektore } \\
\text { p-waardes }\end{array}$} & \multicolumn{2}{|c|}{$\begin{array}{l}\text { Batewaarde } \\
\text { p-waardes }\end{array}$} & \multicolumn{2}{|c|}{$\begin{array}{c}\text { Verkoopsinkomse } \\
\text { p-wardes }\end{array}$} & \multicolumn{2}{|c|}{$\begin{array}{l}\text { Werknemers } \\
\text { p-wasardes }\end{array}$} \\
\hline & Kwartiele & Mediaan & Kwartiele & Mediann & Kwartiele & Mediann & Kwartiele & Mediann \\
\hline Inkomstemarges & 0.9578 & 0.5630 & 0.3409 & 0.9218 & 0.1086 & 0.2367 & 0.1671 & 0.5453 \\
\hline Likiditeit & 0.8384 & 0.6750 & 0.6733 & 0.3356 & 0.6764 & 0.2335 & 0.5722 & 0.8127 \\
\hline \multicolumn{9}{|l|}{ Omloopsnelhede } \\
\hline (Aktiwiteit) & 0.5496 & 0.6003 & 0.8476 & 0.4751 & 0.6988 & 0.9080 & 0.7066 & 0.2733 \\
\hline Rentabiliteit & 0.8824 & 0.8844 & 0.5350 & 0.9005 & 0.1062 & 0.1842 & 0.5504 & 0.5739 \\
\hline Solvabiliteit & 0.7390 & 0.9916 & 0.0844 & 0.1168 & 0.3364 & $0.0147^{*}$ & 0.3426 & 0.8746 \\
\hline Kontantvloeistaat & 0.7306 & 0.9824 & 0.4764 & 0.1018 & 0.9773 & 0.2187 & 0.9006 & 0.5499 \\
\hline
\end{tabular}

vorm 'n faktor (Struwig, 1991: 307; Gombola \& Ketz, 1983: 46).

Met die inagneming van die moontlik ontoereikende steekproefgrootte is besluit om ' $n$ verkennende faktoranalise uit te voer. Die tegniek wat in die BMDP-program vir die onttrekking van faktore gebruik is, is hoofkomponentanalise. Oblimin rotasie is uitgevoer ten einde vir waarskynlike interkorrelasies tussen faktore toe te laat.

Die volgende prosedure is tydens die faktoranalise gevolg. In die eerste plek is die 41 verhoudingsgetalle as veranderlikes ingevoer met die instruksie dat dit in ses faktore verdeel moet word (in die vraeboog is aanvanklik ook vir ses kategorieë voorsiening gemaak). Die ladings van die volgende verhoudingsgetalle was baie laag en is tydens die tweede rotasie buite rekening gelaat: rentabiliteit van beleggings (ladings van $0.254,0.288$ en $0.265 \mathrm{met}$ 'n gemiddelde gebruik van $27.4 \%$, kyk na Tabel 4A); finansiële hefboomfaktor (ladings van $0.386,0.286$ en 0.272 ; 'n relaLiewe ingewikkelde berekening met 'n gemiddelde gebruik van $36.51 \%$, kyk na Tabel 4A); eksploitasiekoëffisiënt ('n lading van 0.275 ; ' $n$ onbekende soort berekening met 'n gemiddelde gebruik van $12.7 \%$ volgens Tabel $4 \mathrm{~A}$ ) en die vaste verpligtinge dekkingsverhoudingsgetal ('n lading van 0.344 en ' $n$ gemiddelde gebruik van $13.9 \%$ volgens Tabel $4 \mathrm{~A}$ ). Die geroteerde faktormatriks van die verskillende verhoudingsgetalle verskyn in Tabel 6. Die variansie verklaar deur ses faktore beloop $58.2 \%$. Indien by 'n opvolgstudie die faktore verder gesuiwer word, behoort hierdie persentasie te verhoog.

By Faktor 1 van Tabel 6 is ses van die sewe verhoudingsgetalle vanuit die kontantvloeistaat saamgegroepeer met die omloopsnelheid van kontant. 'n Analise van die aard van die laasgenocmde bevestig die rasionaal van die samevoeging.

Drie rentabiliteitsverhoudinge en twee solvabiliteitsverhoudinge is by Faktor 2 saamgevoeg. 'n Inspeksie van die berekeningswyse van die voorkeur- en gewone dividenddekkingsverhoudings dui daarop dat albei hierdie verhoudings, net soos rentabiliteit, wesenlike opbrengsparameters verteenwoordig.

By Faktor 3 word vier soorte inkomstemarges en twee likiditeitsverhoudings (omlooptyd van voorrade en debiteure) bymekaar gegroepeer. Verkoopsinkomste speel 'n belang- rike rol by hierdie saamgegroepeerde verhoudingsgetalle, dit wil sê, die oorvleuelende aard van verhoudingsgetalle oor die algemeen, tree sterk op die voorgrond.

Vier maatstawwe van solvabiliteit en een likiditeitsverhoudingsgetal (kontantverhouding) verskyn saam by Faktor 4. Aangesien solvabiliteit likiditeit in wese oor die lang termyn verteenwoordig, is hierdie saamvoeging verstaanbaar.

Die verskillende omloopsnelhede van bates, behalwe die van voorrade en kontant, is by Faktor 5 verenig. By Faktor 6 word die vlottende en vuurproefverhoudings bymekaar geplaas.

'n Ontleding en vergelyking van die ses faktore van die faktoranalise met die ses kategoriě̌ en sy samestellende 41 verhoudingsgetalle (kyk ook na Bylaag A) wat vir die doel van die studie gebruik is, toon bepaalde afwykings ten opsigte van groepering. Die enigste gevolgtrekking waartoe in hierdie stadium gekom kan word, is dat die klassifisering van verhoudingsgetalle volgens rentabiliteit, inkomstemarges, omloopsnelheid (aktiwiteitsverhoudings), likiditeit, solvabiliteit en die kontantvloeistaat, nie in 'n groot mate van die faktore verskil soos in Tabel 6 voorgestel nie. Indien daar wel verwarrende samevoegings binne 'n faktor plaasvind, moet dit nie die navorser ontmoedig nie (Chen \& Shimerda, 1981: 54).

\section{Omvang van gebrulk van die Du Pont-analise}

Die volgende basisvergelyking is aan die respondente voorgelê:

\section{Ondememingsrentabiliteit $x$ hefboomfaktor $=$ rentabiliteit van eie kapitaal<smiles>[CH2-]CC</smiles> \\ Ondernemingsinkomstemarge $\mathrm{x}$ omloopsnelheid van bates}

Slegs $48.2 \%(\mathrm{~N}=79)$ van die respondente het aangedui dat hulle met hierdie basisvoorstelling van die Du Pont-analise vertroud is. Vanuit hierdie kategorie het net $55.1 \%(\mathrm{~N}=43)$ aangedui dat hulle wel hierdie berekening uitvoer. Dit bring 'n gemiddelde gebruiksresponsie van $34.6 \%$ mee. 
Tabel 6 'n Geroteerde faktormatriks van die verskillende verhoudingsgetalle

\begin{tabular}{|c|c|c|c|c|c|c|}
\hline Verhoudingsgetalle & Faktor 1 & Faktor 2 & Faktor 3 & Faktor 4 & Faktor 5 & Faktor 6 \\
\hline \multicolumn{7}{|l|}{ Netto vlottende bate tot kontant uit onder- } \\
\hline nemingsaktiwiteite & 0.864 & 0.000 & 0.000 & 0.000 & 0.000 & 0.000 \\
\hline Vottende bate-omsetverandering & 0.835 & 0.000 & 0.000 & 0.000 & 0.000 & 0.260 \\
\hline Kontantvloei vir finansieringskoste & 0.719 & 0.000 & 0.000 & 0.000 & 0.000 & 0.000 \\
\hline Kontant vir kapitaalaflossing & 0.616 & 0.000 & 0.000 & 0.000 & 0.000 & 0.000 \\
\hline Kontantinvesteringsverhouding & 0.596 & 0.000 & 0.000 & 0.000 & 0.000 & 0.000 \\
\hline Kontantvloei-omset-verhouding & 0.580 & 0.000 & 0.000 & 0.307 & 0.000 & 0.000 \\
\hline Kontantomloopsnelheid & 0.572 & 0.000 & 0.000 & 0.000 & 0.000 & 0.000 \\
\hline Gewone dividenddekking & 0.000 & 0.826 & 0.000 & 0.000 & 0.000 & 0.000 \\
\hline Opbrengsverhoudings (VPA en DPA) & 0.000 & 0.801 & 0.000 & 0.000 & 0.000 & 0.000 \\
\hline Rentabiliteit van beherende kapitaal & 0.000 & 0.679 & 0.000 & 0.000 & 0.000 & 0.000 \\
\hline Voorkeurdividenddekking & 0.273 & 0.627 & 0.000 & 0.000 & 0.000 & 0.000 \\
\hline Rentabiliteit van eie kapitaal & 0.000 & 0.609 & 0.000 & 0.000 & 0.000 & 0.000 \\
\hline Dae se verkope in voorrasd & 0.000 & 0.000 & 0.788 & 0.280 & 0.000 & 0.000 \\
\hline Bruto inkomstemarge & 0.000 & 0.000 & 0.668 & 0.000 & 0.000 & 0.000 \\
\hline Debiteure invorderingstermyn & 0.000 & 0.000 & 0.640 & 0.000 & 0.000 & 0.000 \\
\hline Ondememingsinkomstemarge & 0.000 & 0.000 & 0.587 & -0.361 & 0.000 & 0.000 \\
\hline Bedryfsmarge & 0.000 & 0.000 & 0.562 & 0.000 & 0.000 & 0.000 \\
\hline Netto inkomstemarge & 0.251 & 0.000 & 0.549 & 0.000 & 0.000 & 0.000 \\
\hline Solvabiliteitsverhouding & 0.000 & 0.000 & 0.000 & 0.652 & 0.000 & 0.000 \\
\hline Kontantverhouding & 0.000 & 0.000 & 0.000 & 0.560 & 0.000 & 0.000 \\
\hline Kortkredietverhouding (KTVK:TVK) & 0.000 & 0.000 & 0.000 & 0.558 & 0.000 & 0.000 \\
\hline Langkredietverhouding & 0.000 & 0.000 & 0.000 & 0.545 & 0.000 & 0.000 \\
\hline Vreemde kapitaalverhouding & 0.000 & 0.000 & 0.000 & 0.533 & 0.000 & 0.318 \\
\hline Omloopsnelheid van totale bates & 0.000 & 0.000 & 0.000 & 0.000 & 0.844 & 0.000 \\
\hline Omloopsnelheid van vaste bates & 0.000 & 0.000 & 0.000 & 0.000 & 0.744 & 0.000 \\
\hline Omloopsnelheid van vlottende bates & 0.000 & 0.000 & 0.000 & 0.306 & 0.687 & -0.298 \\
\hline Vottende verhouding & 0.000 & 0.000 & 0.000 & 0.000 & 0.000 & 0.843 \\
\hline Vuurproefverhouding & 0.000 & 0.000 & 0.000 & 0.000 & 0.000 & 0.766 \\
\hline \multicolumn{7}{|c|}{ * Faktore met 'n lading $<0.2500$ word aangetoon as 0.000} \\
\hline & & & & & & \\
\hline
\end{tabular}

Tabel 7 Uitgangspunte by die vasstelling van norme vir finansiêle verhoudingsgetalle

\begin{tabular}{llrr}
\hline \multicolumn{2}{c}{ Uitgangspunt } & Aantal & $\%$ \\
\hline 1 & Norme gegrond op die ervaring van 'n spesi- & & \\
& fieke ondememing & 31 & 18.7 \\
2 & Bedryfstaknorme (Bedryfsvergelyking) & 17 & 10.2 \\
3 & Algemene ervaringsreëls of empiriese anvaar- & & \\
& de norme & 10 & 6.0 \\
$4 \quad$ Kombinasie van (1), (2) en (3) hierbo & 96 & 57.8 \\
$5 \quad$ Ander uitgangspunte & 12 & 7.2 \\
\hline & Total & 166 & 100 \\
\hline
\end{tabular}

\section{Vergelykingsnorme}

Respondente is daaraan herinner dat 'n verhoudingsgetal as sodanig nie veel sê nie en dat 'n norm vir vertolkingsdoeleindes benodig word. In Tabel 7 word die uitgangspunte by die vasstelling van norme aangedui.

By 'ander' van Tabel 7 is uitgangspunte ingesluit soos norme wat deur die beherende onderneming of groep ondernemings voorgeskryf word.

\section{Persepsies ten opsigte van dle uitstaande voor- en nadele van flnansiêle verhoudingsgetalle}

In die vraeboog is ruimte gelaat waar respondente die vooren nadele verbonde aan finansiële verhoudingsgetalle volgens hul praktykervaring kon aanteken. Uiteraard is wyd uiteenlopende responsies ontvang. Die voor- en nadele is elk in vyf kategoriez groepeer. Hierdie inligting verskyn in Tabelle 8 en 9.

\section{Gevolgtrekkings}

'n Verkenningstudie van hierdie aard het nadele wat in hierdie geval veral met die relatiewe klein steekproef verband hou. Andersyds is die nodige voorsorg getref ten opsigte van die betroubaarheid van die ingesamelde inligting.

Van besondere belang is die volgende aspekte wat in hierdie studie na vore tree:

- Die belangrike rol wat inkomstemarges in die praktyk speel, in die besonder die ondernemingsinkomstemarge, 
Tabel 8 Voordele verbonde aan finansielle verhoudingsgetalle $(\mathrm{N}=166)$

\begin{tabular}{|c|c|c|c|}
\hline & Kalegorie & Aantal & 9 \\
\hline 1 & $\begin{array}{l}\text { Beplanning en beheerdoeleindes/Gerig op } \\
\text { ondememingsdoelwitte/minimiseer risiko }\end{array}$ & 91 & 54.8 \\
\hline 2 & $\begin{array}{l}\text { Identifisering van veranderlikes/pro- } \\
\text { bleme/neigings/probleemgebiede }\end{array}$ & 80 & 48.2 \\
\hline 3 & Vergelykingsdoeleindes/Prestasiebeoordeling & & \\
\hline & Vorige jare/ander ondememings & 51 & 30.7 \\
\hline 4 & Opsomming van inligting & 24 & 14.5 \\
\hline 5 & Diverse/Eenvoudige analises & 25 & 15.1 \\
\hline
\end{tabular}

Tabel 9 Nadele verbonde aan finansiêle verhoudingsgetalle $(\mathrm{N}=166)$

\begin{tabular}{llll}
\hline & \multicolumn{1}{c}{ Kategorie } & Aantal & $\%$ \\
\hline 1 & Historiese karakter/Mag misleidend wees & 71 & 42.8 \\
2 & Betekenisloos sonder norme & 30 & 18.1 \\
3 & Vergelykings nie altyd moontlik nie & 28 & 16.9 \\
4 & Gee nie altyd die werklike situasie weer nie & 24 & 14.5 \\
5 & $\begin{array}{l}\text { Diverse: Te veel verhoudings/Gee nie afwy- } \\
\text { kings weer nie }\end{array}$ & 36 & 21.7 \\
\hline
\end{tabular}

die bruto inkomstemarge, die bedryfsmarge en netto inkomstemarge.

- In diesclfde konteks moet ewe belangrike verhoudingsgetalle soos die debiteure invorderingstermyn, die vlottende verhouding en die debiteure omloopsnelheid vermeld word.

- Veral opmerklik is die verskynsel dat verhoudingsgetalle wat met die kontantvloeistaat ('n verpligte opgawe vir maatskappye wie se finansiële jaar op of na 1 Oktober 1988 begin) verband hou, nie algemeen deur die respondentondernemings gebruik word nie.

- Deur middel van meervoudige analise van variansie is vasgestel dat die onafhanklike veranderlikes soos hoofaktiwiteite en verskillende parameters van grootte nie 'n invloed op die gebruik van die kategorieè finansiële verhoudingsgetalle het nie. Hierdie bevinding impliseer egter nie dat sleutelverhoudingsgetalle van byvoorbeeld ' $n$ supermark direk vergelykbaar is met die van 'n motorvervaardiger nie. Dit impliseer hoogstens dat die omvang van die gebruik van die verhoudingsgetalle nie betekenisvol verskil nie. Die outeurs is egter van mening dat hoofaktiwiteite en grootte wel 'n rol speel - 'n aspek wat in 'n opvolgstudie weer aangespreek gaan word. Die teenswoordige bevinding hou waarskynlik met die relatief klein getalle en die samevoegings wat vir ontledingsdoeleindes gedoen is, verband. As gevolg hiervan het die onderskeidende kenmerke van bedryfstakke en die moontlike effek van grootte op die gebruik van verhoudingsgetalle, verlore gegaan.

- Die gebruik van faktoranalise om 'n verskeidenheid verhoudingsgetalle te reduseer, toon dat die groeperinge nie volkome met teoretiese groeperinge ooreenstem nie.

\section{Verdere navorsing}

Hierdie verkenningstudie wys daarop dat verdere navorsing in hierdie domein veral aandag op die volgende aspekte behoort te vestig:

- die inkorporering van die ondernemingsvorm as 'n onafhanklike veranderlike;

- die ontleding van werklike data soos opgesluit in die verhoudingsgetalle waaruit bepaalde norme mag voortvloei;

- die verband tussen aandeelhouerswelvaartmaksimering en die omvang van die berekening van verhoudingsgetalle;

- die verband tussen algemene ekonomiese aktiwiteite en die gebruik van bepaalde verhoudingsgetalle;

- die oorweging om spesifieke verhoudingsgetalle wat weens bepaalde redes nie gebruik kan word nie, uit te skakel (byvoorbeeld, die debiteure invorderingstermyn is corbodig by 'n onderneming wat slegs teen kontant verkoop); en

- die inkorporering van ondernemings op 'n nasionale grondslag met ' $n$ besondere fokus op die gebruik van verhoudingsgetalle deur instellings soos banke en die versekeringsbedryfstak, aandele makelaars, finansiële joernaliste en die Buro vir Finansièle Analise.

Samevattend: soos dit behoort te wees, blyk dit dat ook hierdie studie meer vrae skep as wat dit beantwoord!

\section{Summary}

To learn more about the actual use of meaningful financial ratios by business practice, an empirical survey was conducted. Final-year students in Financial Management of the University of Port Elizabeth administered the questionnaire canvassing the opinions of business management on the use of financial ratios. Responses were received from 166 firms. The Likert scale was used to establish the frequency of use of the following categories of financial ratios, namely return on assets, income margins, capital turnover, solvency and ratios derived from the cash flow statement. A total of 41 financial ratios were submitted to the respondents. Salient findings included the following: income margins and debtors collection period as groups of ratios dominated the other categories. Further, with the help of multiple analysis variance, it was established that the main activities and size of respondents had no influence on the use of specific categories of financial ratios. By means of factor analysis, noticeable similarities were found between groupings of ratios as presented in theory and the results of the empirical survey. The respondents were also questioned whether they were familiar with the Du Pont analysis, the use of norms to compare ratios and their perceptions on the prominent advantages and disadvantages of financial ratios.

\section{References}

Altman, E.I. 1968. 'Financial ratios, discriminant analysis and the prediction of corporate bankruptcy', Journal of Finance. September.

Beaver, W.H. 1968. 'Alternative accounting measures as predictors of failure', The Accounting Review, January.

BMDP Statistical Software. PC 90. 1990. California: University of California Press.

Bliss, J.H. 1923. Financial and operating ratios in management. New York: Ronald Press. 
Boy. A.D. 1979. 'Some results of an empirical study of ratio analysis in South Africa', The Investment Analysts Journal. No. 13.

Buro vir Finansiële Analise. 1989. Handleiding vir die gebruikers van die BFA verhoudingsgetaldiens. Verslag A. 5A(H). Pretoria: Universiteit van Pretoria.

Chen, K.H. \& Shimerda. T.A. 1981. 'An empirical analysis of useful financial ratios', Financial Management, Spring.

Collins, D. 1976. 'Some fallacies in finanical analysis', The Invesument Analysts Jowrnal, No. 7.

Deakin, E.B. 1972. A discriminant analysis of predictors of business failure', Journal of Accounting Research, Spring.

De la Rey, J.H. 1981. Finansiële verhoudingsgetalle en die voorspelling van finansiële mislukking by nywerheidsondernemings in die Republiek van Suid-Afrika. Ongepubliseerde proefskrif. Pretoria: Universiteit van Pretoria.

Edmister, R.O. 1972. 'An empirical test of financial ratio analysis for small business failure prediction', Journal of Financial and Quantisative Analysis, March.

Foster, G. 1986. Financial statement analysis. Second Edition. Englewood Cliffs, New Jersey: Prentice-Hall.

Foulke, R.A. 1961. Practical financial stalement analysis. Fifth Edition. New York: McGraw-Hill.

Gibson, C.H. 1992. Financial statement analysis. Fifth Edition. Cincinnati: South-Westem Publishing.

Gombola, M.J. \& Ketz, J.E. 1983. 'Financial ratio patterns in re- tail and manufacturing organizations'. Financial Management. Summer.

Helfer, E.A. 1991. Techniques of financial analysis. Seventh Edition. Boston: Irwin.

Lambrechts, I.J. (red.). 1990. Finansiële bestuur. Pretoria: Van Schaik.

Lee, C.F. 1985. Financial analysis and planning: theory and ap. plication. Reading, Massachusets: Addison-Wesley.

Maness, T.S. \& Henderson, J.W. 1991. Financial analysis and forecasting. Englewood Cliffs: Prentice-Hall.

Myer, J.N. 1969. Financial statement analysis. Fourth Edition. Englewood Cliffs: Prentice-Hall.

Paarlberg, D. 1968. Greath myths of economics. Ohio: The New American Library.

Parasuraman, A. 1991. Marketing research. Second Edition. Texas: Addison-Wesley.

Potgieter, JJ. \& Frank, A.P. 1990. Ratio analysis and interfurm comparisons as a means of providing management information in the small business sector. Publication series of the University of Zululand. Series B, No. 75.

Seitz. N. 1979. Financial analysis: a programmed approach. Second Edition. Reston: Reston Publishing.

Struwig, F.W. 1991. Intrapreneurship: a strategy for managing change and innovation. Unpublished PhD Thesis. Vista.

Viscione, J.A. 1977. Financial analysis: principles and procedures. Boston: Houghton Mifflin.

Warren, B.O. 1991. Financial analysis. Lynn East: Renall.

Bylaag A Kategoriex van finansiěle verhoudingsgetalle en berekeningswyse

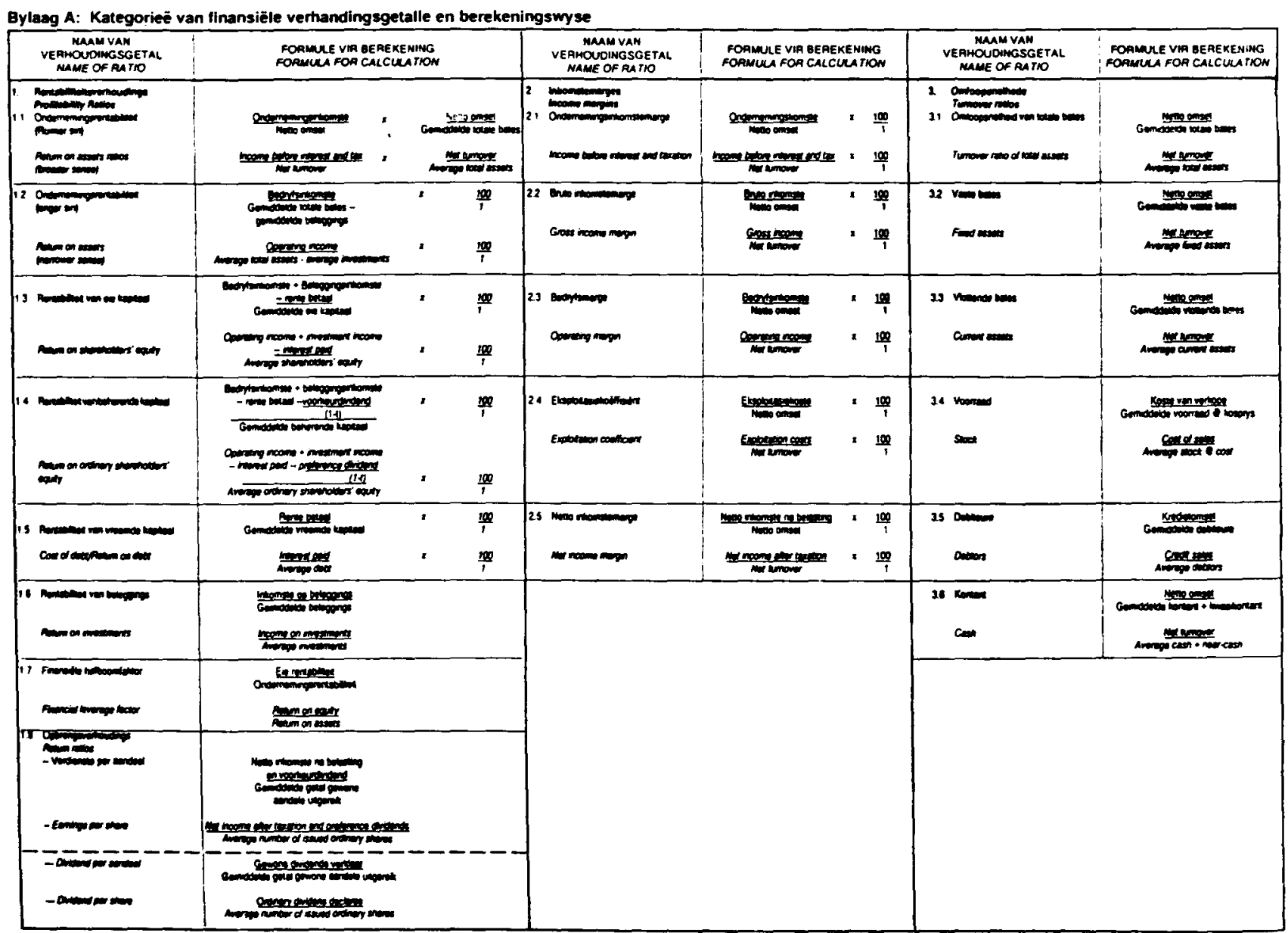




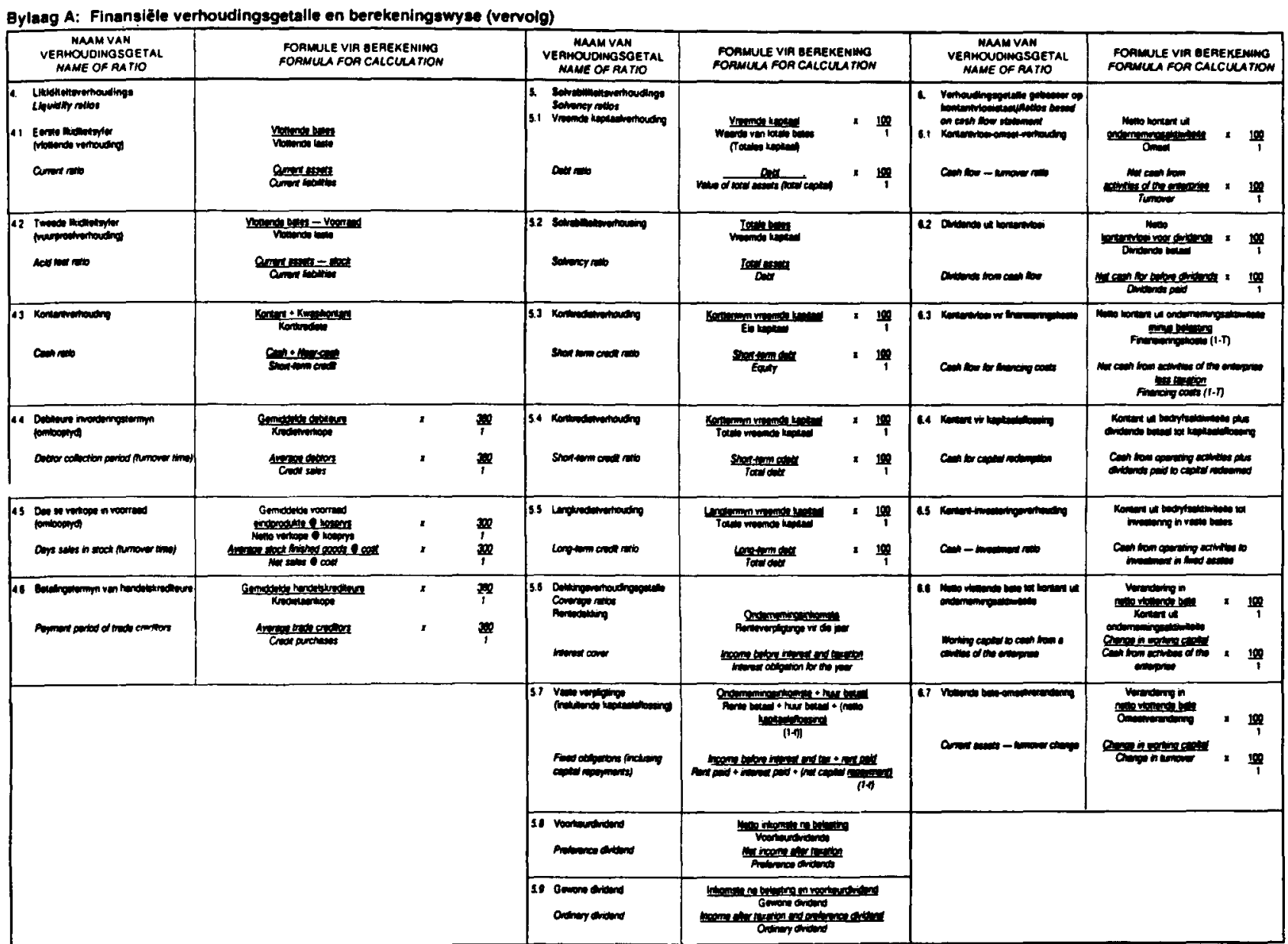

